\title{
PRESIDENT LEGTURE
}

Analysis of Constitutions by Mathematical Principle

I. The Analysis of Obese-Diabetic and Obese-Normal Constitutions

K. YAMADA

Department of Internal Medicine, Nagoya University School of Medicine, Nagoya (See pp. 335 342)

SPEGIAL LEGTURE

Dual Mechanism of Hormonal Regulation on the Catabolic Enzymes in Rat Liver

\section{SUDA}

Division of Protein Metabolism, Institute for Protein Research, Osaka University, Osaka (See pp. 343 352)

\section{The Central Nervous Control of Ovulation}

\section{T. KOBAYASHI}

Department of Obstetrics \& Gynecology, Faculty of Medicine, University of Tokyo, Tokyo (See pp. 353 371) 


\section{特 別 講 演 \\ ホルモンによる代謝制御 \\ 一合成系及び分解系への相反作用一}

大阪大学 蛋白質研究所

須田正 巳

\section{（1）序論}

ホルモンによる代謝の律速を考学る場合，私は以下の様な立場から問題をとりあげてみたい，ホルモンは 体液を介して, 標的器官の代謝ないしは律速䤏素を, 制御する chemical messenger であるから, message の持続性は，必要に応じて合目的に停止されるか，逆に message の感度が増幅される，ての反応は，異種 ホルモン間で絶えず, 調節されている。一方, 単一の chemical messenger でも, 同じ臟器の同一細胞内に 作動している醉素の生理的合目性に応じて, 全く相反する律速を誘導する。省故, chemical messenger 相互間の作動機構については, direct か indirect な counteraction が存在し得る.

以上の外に, ホルモン分泌臓器間の feedback 制御の問題及び自律神経系による直接かつ, 緊急な律速醉 素活性の制御とホルモンの関係についての問題があるが，今回は，上述の観点にしぼつて，主として，私共 の研究室で行われて来た成績について解説したい，そして本論に入る迄に，以上の立場（方法論）に立つて ホルモンの研究をする場合, 研究の方法（方法論ではなくて）について，若干の意見を述べて置きたい，従 来, ホルモンの生理作用を観察する場合, in vivo 系で, ホルモン分泌臟器を破壊 (alloxam 糖尿, goldthioglucose による視床下部破壊等)，或は外科的摘出又は分泌抑制などが利用され，従つて当該ホルモンの 分泌脱落症状と，そのホルモンの補給による症状の回復という方法が普遍的であつた。しかし乍ら，上述の 観点からすると，脱落症状はむしろ，そのホルモン (chemical messenger) の脱落又は劣勢状況下で，それ と本来, 拮抗する対応ホルモンが predominant な状況になるため, 対応情報の持続的放出下でみられる異 常代謝なのである．こうした相補的立場から，はじめてホルモンによる生体内恒常性の維持とその破綻につ いて——非常に複雑かつ困難な研究分野であるが——分析が進められると思う。一方, ホルモンの研究方法 として in vitro のシステムを利用出来る，勿論 in vitro 系は，in vivo 系をそのまま反映するものではな いが，in vivo 系では分析困難なホルモンの作用機序を，その採用した方法に応じて，数段階のレベル（分 子レベルまで含めて）で解析出来る。 in vitro 系での代表的なものをあげれば（1)藏器環流法 (perfusion) （2）組織切片系(slice level）（3）細胞浮遊法(dipersed cell level）(4)組織培養 (tissue culture) (5) 無細胞系 (cell free system) が考えられる。ホルモンが細胞内の情報伝達系 (repressor $\rightarrow$ operater $\rightarrow$ cistron $(D N A) \rightarrow$ messenger RNA $\rightarrow$ ribosome $\rightarrow$ 蛋白形成) に対して，どてかの段階で， derepression 機構を通じて，作用 しているらしいととは，次第に明になつているし， endoplasmic reticulum 系に作用して生体膜系に影響 をあたえることも理解されよう。こうした，いわば molecular level の研究と共鲬して，他方で，ホルモン が homeostasis を維持する生理化学的な意味を, 適確な marker を使つて, 適切な場 (方法) で, 明にし てゆくととも, 同じく重要な研究分野である. この両側面からの研究は次元が異つている様にに見えるけれ ども生体内では連動しているわけであつて研究自体が分極しているに過ぎない. 


\section{（2） ホルモンによる相反的代謝律速}

私共はすでに白鼠肝藏の glucokinase (GK) と serine 脱水酵素 (SDH) が， insulin 又は hydrocortisone の dominat な状態下で，相反的 (reciprocal) に，その活性が変動することを報告しだ). Fig. 1 はその 総括関係を示したものである. glucokinase と SDH をなぜ marker として選んだかについては, Fig. 1 の

Fig. 1. Activities of serine dehydratase and 下図に示してある様に前者は血糖を解糖系にとり込む 最初の段階の酵素で, glucose 6 燐酸を形成, 後者は serine を脱アミノ化して pyruvate を形成する。 glucose-6 燐酸と pyruvate とは, 結局, 解糖及び糖 新生系の両末端にあたる代謝物である. 白鼠にアロキ サン $(50 \mathrm{mg} / \mathrm{kg}$ 体重) を注射後約 2 日後には(VII)の様 に GK 活性は減少し, SDH 活性は反対に増大する。 この様な動物に，覀鉛プロタミン・インシュリン $(6.5$ 単位/1日) と, 実験前 5 時間, 29時間, 53時間の 3 回 筋肉注射すると（II）の様に正常化する。乙の様に GK と SDH の逆相関関係について, ホルモンの生理的意 義と合目的な作用機序が考えられた（V)（VI）の両酵 素活性を見られたい，3 日間絶食或は $91 \%$ \% イン食 (無炭水化物食) 3 日間飼育ということは何を意味する かといえば，乙の様な飼育状態でも動物は血糖を維持 する為に, 肝臓で pyruvate $\longrightarrow$ glucose・6・燐酸 $\longrightarrow$ 血糖の反応が作動している。従つて GK 活性は低下 し, SDH 活性は上昇する。ではこの両酵素を marker とした場合, 上述の insulin 効果は, このホルモンだ けで説明されるべきものであろうか.（III）(IV)では夫 glucokinase in rat liver under various hornal and dietary conditions. Conditions for male Donryu rats :

(I) Normal, (II) diabetic + ihsulin, (III) adrenalectomized, (IV) adrenalectomized $\rightarrow$ diabetic, (V) fasted for 3 days, (VI) fed $91 \%$ casein diet for 3 days, (VII) diabetic, (VIII) adrenalectomized $\rightarrow$ diabetic + hydrocortisone acetate.

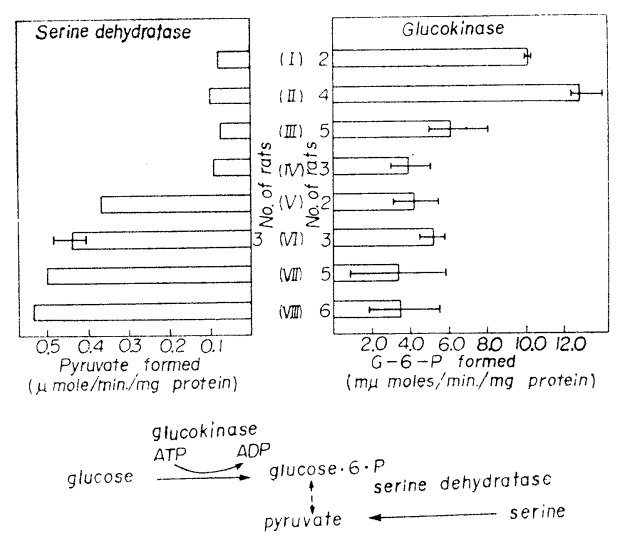

々副腎摘出のもの, 及び摘出後 5 日〜 6 日目に, アロキサン注射, 更に 2 日後に活性測定したものであるが, (IV)では GK の低下が著明であるが，SDH の方は変化が殆んどない．とてろが最後のカラム (VIII) でみら れる様に，副腎摘出—アロキサン糖尿後に hydrocortisone（3回にわけ $5 \mathrm{mg}$ づつ注射）を与えると40時 間後には SDH の著明な活性上昇, GK の低下がみられる。附言したいのは, 副腎摘出動物に, この量のグ ルココルチコイドを注射しても SDH の活性上昇がないとと，及び脳下垂体摘出動物でも全く同様の知見が 得られたことである．以上の事実は，膵臓の $\beta$ 細胞が正常に insulin 考分泌し message を送つていると， その message を打消すだけのグルココルチコイドが分泌されない限り，SDH の活性は上昇せず，GK 活 性は高いが，ホルモンの関係が逆転すれば，SDHは上昇し，GK が低下する。つまり insulinは GK を induce し, hydrocortisone は SDH を induce しつつ, 両ホルモンは相拮抗の作用をもつてとになる.ア ロキサン糖尿, 絶食, $91 \%$ \% イン食の条件下では，グルココルチコイドが dominant の状態であると考 えられる。

この点を一㬝明確に示したのが，肝藏環流法によつて得られ一連の事実である。環流法によるホルモンの 作用を研究する試みは，以前から行われているが，酵素誘導に成功している報告は極めて少く，Knox ${ }^{2}$ らに よる報告があるに過ぎない. 此は環流法の不備によるもので，よく使用されているのは Miller $\left.{ }^{3}\right)$ 開発した 装置であるが，私共は約 7 年程以前からての方法を追試したが，目的に合わない為最近田中らにより，すべて 改造され，全血（約 $90 \mathrm{ml}$ ，ヘパリン 50 単位 $/ \mathrm{ml}$ ）在使用し，ガス交換は Disc-rotating oxygenatorにより， 効果を上げ人工心臓を肝門脈及び静脈側に 2 個使用して陰圧にし, 血液 $\mathrm{pH}$ を PH-stat により自動補正し 
Fig. 2. The induction of glucokinase by insulin in the isolated perfused rat liver.

Triamcinolone, insulin and glucose were added at the concentrations of $10 \mathrm{mg}$, $40 \mu$ and $250 \mathrm{mg} / 100 \mathrm{ml}$ of blood, respectively. No induction of hexokinase was observed during the perfusion shown in Fig. 2

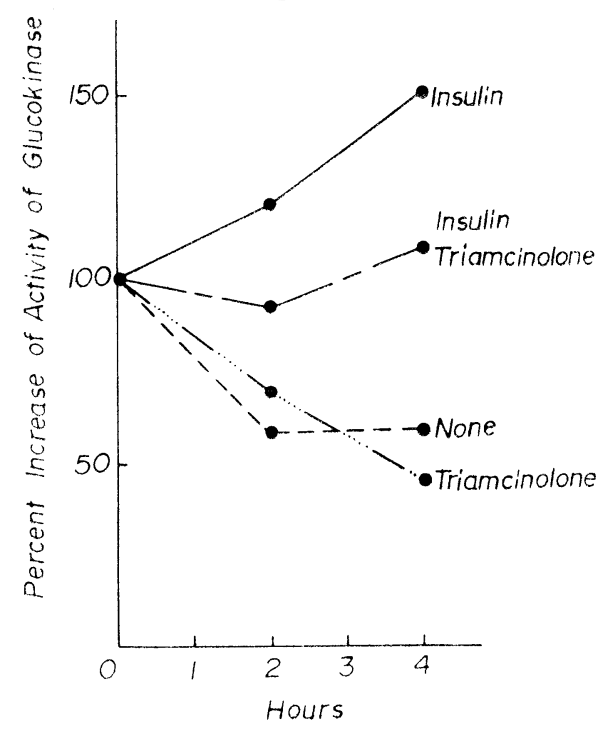

Fig. 3. The inhibition of the induction serine dehydratase by insulin in the isolated perfused rat liver.

For conditions, see the legend of Fig. 2.

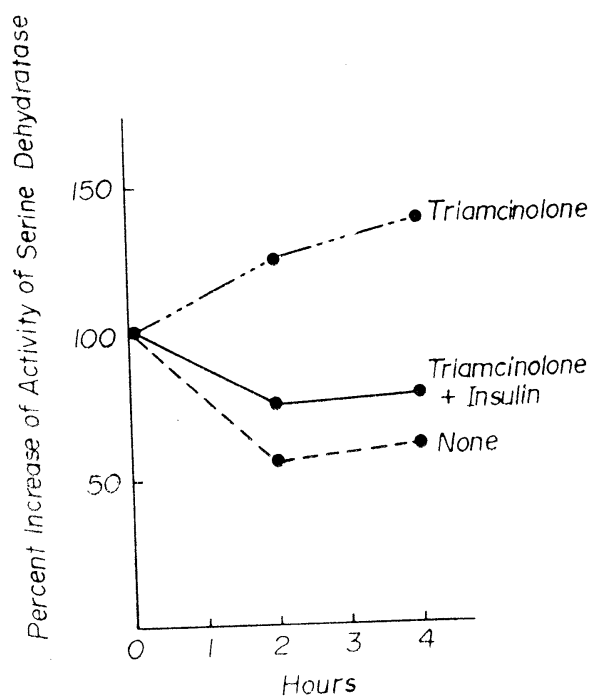

だ). 血流量は毎分 $2.0 \sim 2.5 \mathrm{ml} / \mathrm{g}$ 組織で, 生体内 条件の約 2 倍である. flow rate の低下は肝機能不全 を示した.

Fig. 2 は insuline による GK の誘導, triamcinolone の抑制, insuline 効果に対するtriamicinolone の拮抗を明確に示している。従来 in vivo 系で gluc okinase (肝藏にのみ存在する) は, insulin で誘導さ れることが報告されている5 insulin の作用を明にしたのは此等の報告がはじめて である.ことに動物全体の場で, 両種のホルンによる 拮抗作用については，むしろ否定的な結果が多かつた

Fig. 4. The induction of serine dehydratase by triamcinolone in the isolated perfused rat liver.

For conditions, see the legend of Fig. 2.

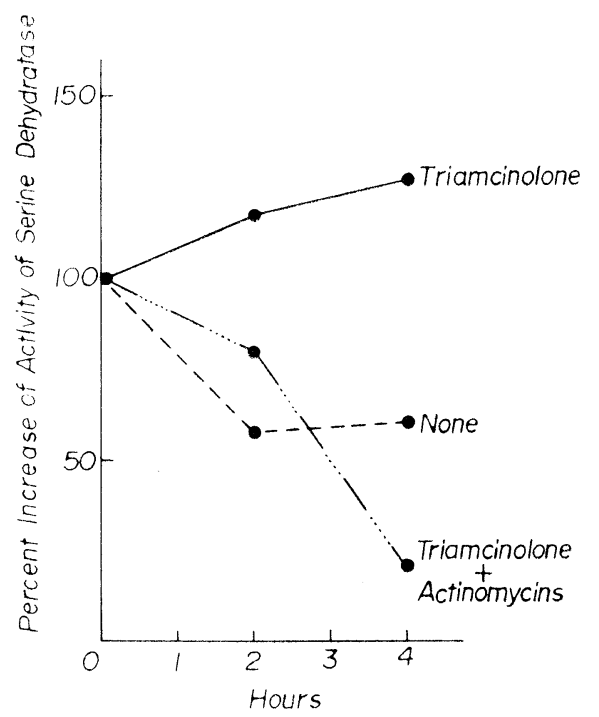

Fig. 5. Crystalline serine dehydratase from rat liver $(\times 400)$.

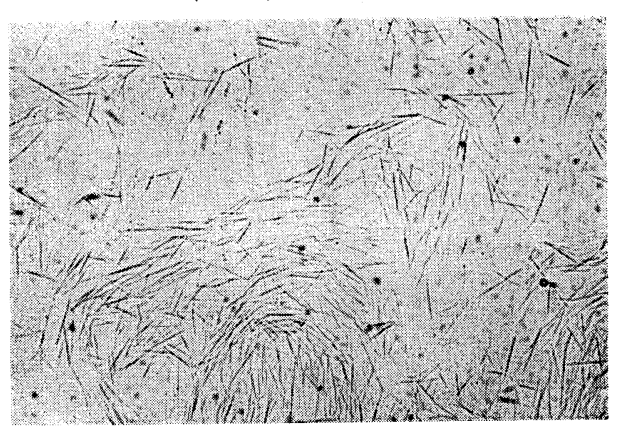


のである. GK 活性の上昇は, 蛋白合成阻害剤である actinomycin $\mathrm{S}(2 \mu \mathrm{g} / \mathrm{ml})$ 亿よつて阻害されるので, de novo の酵素蛋白合成であるととは明である.

Fig. 3, 4 は同じ条件下で, SDH の誘導及び抑制をしらべたものである。乙の場合は，GK と全く相反的 に, SDH は triamcinolone により誘導され, insulin によりその効果が中和されている glucokinase の 場合も, serine 脱水醰素の場合も無添加（Fig. 中 none と記名した線で示す）の時, 活性が下降しているの は, 醳素自体の turn over を示しているのであつて, ホルモン添加時には, それを上廻つて合成度の上昇 があるてとになる。此の点については, 現在 SDH が中川, 木村らによつて, はじめて動物組織 (肝㵴) か ら結晶化され（分子量 63,000), 抗体も得てるので, 醅素蛋白とラベルして, 今後検討したい. Fig. 5 は 白鼠肝臟の SDH の結晶を示したものである.

\section{(3) 合成系及び分解系の酵素に対するホルモンの相反的作用}

Fig. 6 は serine の合成経路が糖代謝路から技分れする branching enzyme として, serine 合成の律 Fig. . 6 Pathways for synthesis and breakown of serine.

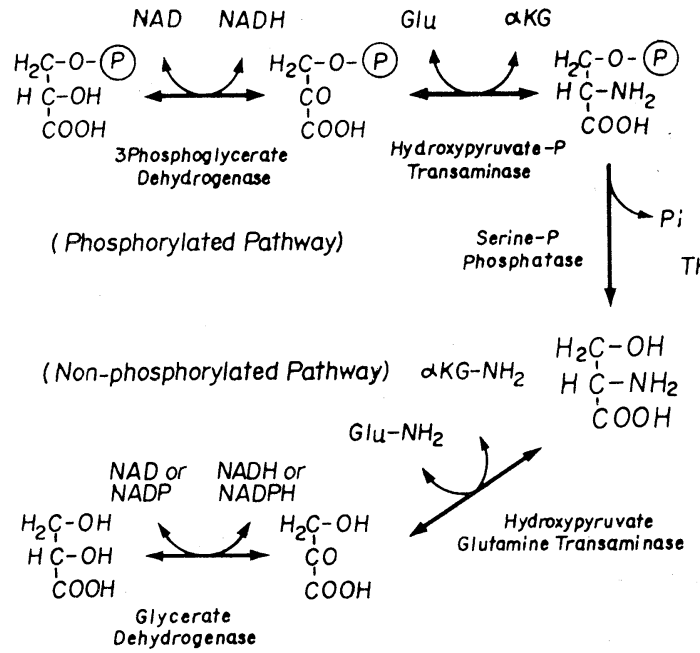

Fig. 7. Effect of casein content in diet on rat liver 3-PGADH and SDH. Rats were fed synthetic diets containing various amount of casein as a nitrogen source for 3 day $\mathrm{s}$ for 3-PGADH and 4 days for SDH.

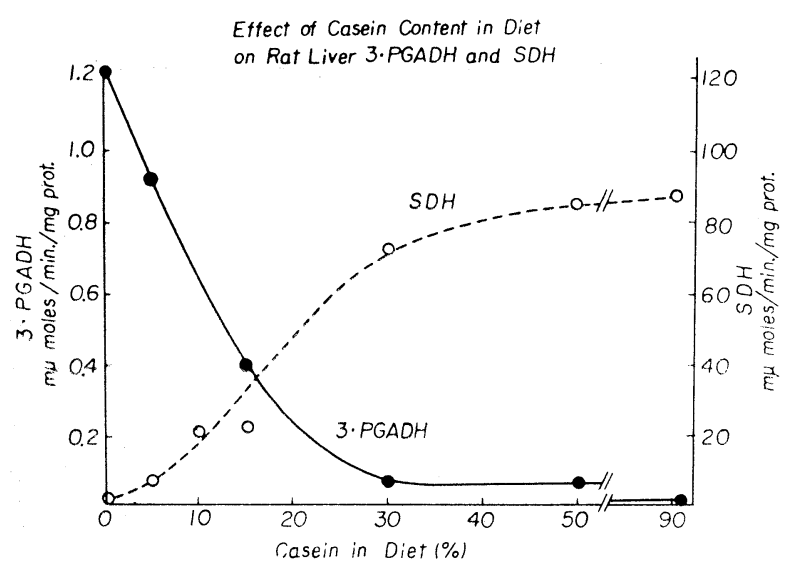

第 43 巻 第 5 号

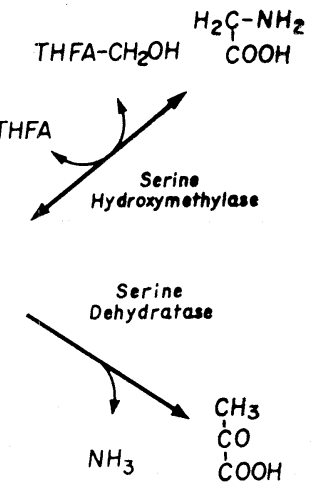

速段階にあたるととを示し7)，一方 上述の様に SDH は serine の分解 に関係する酵素である。 serine の 合成経路としては Sallack $\left.{ }^{8}\right)$ の nonphosphorglated pathway があ るが，てれは律速的役剂を果してい ない点について 私共の成績がある が，省略する。

ここでは 3•phosphoglycerate dehydrogenase(3PGADH) te serine 0 ) anabolic enzyme $\sigma$ marker 及 び SDH を catabolc einzyme の marker としてとり上げ, ホルモン 作働に対する相反的応答について述 べたい. Fig. 7 は白鼠を, 無蛋白食 ↔無炭水化物食で飼育した（3 日〜 
Fig. 8. Effect of Insulin on 3-PGADH and $\mathrm{SDH}$ activities of alloxan diabetic rats.

For 3-PGADH experiment, rats were fed nonprotein diet for 3 days. Alloxan monohydrate, 7 $\mathrm{mg} / 100 \mathrm{~g}$ body weight, was injected intravenously 4 days before the start of the diet. Novo Lente zinc insulin, 8 i.u./100g body weight, was injected intraperitoneally everyday during the non-protein feeding. For SDH, rats were fed laboratory chow throughout the experiment. Alloxan monohydrate, $5 \mathrm{mg} / 100 \mathrm{~g}$ body weight, was intravenously injected 3days before sacrifice. Protamine zinc insulin, 3 i.u./100g body weight/day, was intramuscularly injected. Numbers of rats were indicated in parentheses.

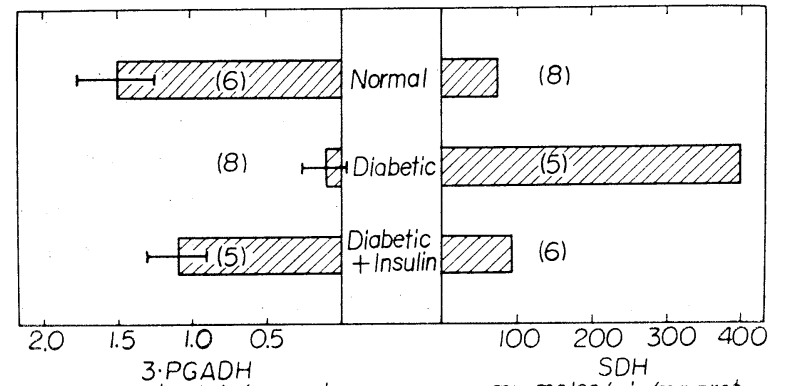

mu moles/min/mg prot.

$\mathrm{mu}$ moles/min/mg prot.

Fig. 9. Effect of triamcinoloneon rat liver 3-PGADH and SDH. For 3-PGADH, rats were fed non-protein diet for 5 days. Triamcinolone, $2 \mathrm{mg} / 100 \mathrm{~g}$ body weight, was injected intraperitoneally everyday during the feeding. For SDH, rats were fed a synthetic diet containing essential amino acid mixture and sodium glutamate for 9 days. Triamcinolone, $1 \mathrm{mg} / 100 \mathrm{~g}$ body weight, was injected intraperitoneally for the last 2 days. Numbers of rats were indicated in parentheses.

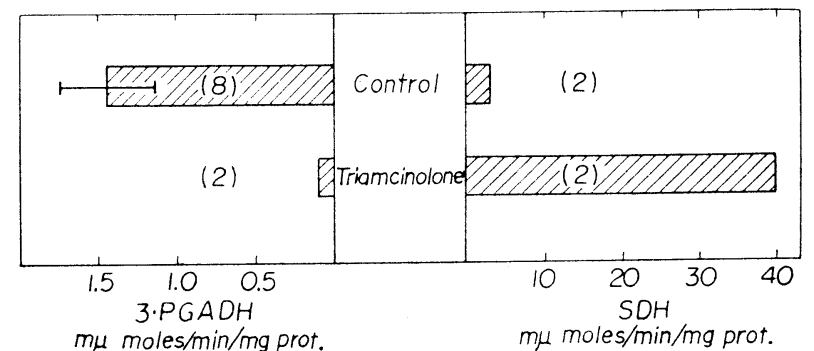

4 日）後の $3 \mathrm{PGADH}$ 及び $\mathrm{SDH}$ の 活性を変動示している. 全く相反的 であることからホルモンによる相反 作用が潜在することを予想させる.

Fig. 8 は，アロキサン糖尿の場合と それに insulin を注射した場合の 兩酵素活性の相反的応答を示した. 糖尿症或はFig. 7 の高蛋白食飼育の 様な, 糖新生に代謝が傾いている場 合は, serine の合成律速を左右する 3PGADH 活性は低下して, 分解が 増大して pyruvate を供給する。乙 の事実は次の Fig. 9 亿更に明に示 される、つまり serine の合成系は insulin と拮抗する triamcinolone で著明に抑制され，他方 SDH は既 述の様に誘導合成される。 catabolic hormone といわれる. グルココル チコイドが, 非必須アミノ酸の合成 を抑制している点が興味がある点で あろう.しかし, 動物を副腎摘出 $\rightarrow$ アロキサン糖尿の条件下に置いて も,つまり insulin, glucocorticoides の作㗢外においた条件下でも, 食䬣 性変化に対し 3PGADH が変動(無 蛋白食で活性が高まり, 高蛋白食で 低下する）が涩められたので，他種 のホルモンととに下垂体ホルモンの 中で, growth hormone の影響を問 題にした. Fig. 10 で示す様に，成 長ホルモン（必ずしも成長期にのみ 作㗢するものではない）は，合成系 を高める一方, serine の分解系を 抑制している。

growthhormone が, 直接に3PGDH に代表される様は anabolic enzyme を誘導するか否かについ て，その機作は未だ不明であるが， 一方ではアミノ酸の合成を高め他面

では, SDH に代表される様なその分解酵素の増大を抑制する点は, このホルモンの生理作用としての一面 を物語つている.乙れに対して Fig. 9 の triamcinolone の影響は全く相反的である.

一般に, catabolic steroide といわれている hydrocortisone の作用については, 乙の際充分, 藏器相関と いう面から考えなければならない，てのホルモンが優位にある状態下では, 生体内藏器で, 体内必要物質の 
Fig. 10. Effect of growth hormone on rat liver 3-PGDH and SDH. For 3-PGDH, rats were fed non-protein or 30\% casein diet for 3 days. Bovine growth hormone (NIH), $0.1 \mathrm{mg} / 100 \mathrm{~g}$ body weight/day was injected intraperitoneally during the period. For $\mathrm{SDH}$, rats were fed laboratory chow or starved for 3 days. Bovine growth hormone, $0.1 \mathrm{mg} / 100 \mathrm{~g}$ body weight/day, was injected intraperitoneally during the period.

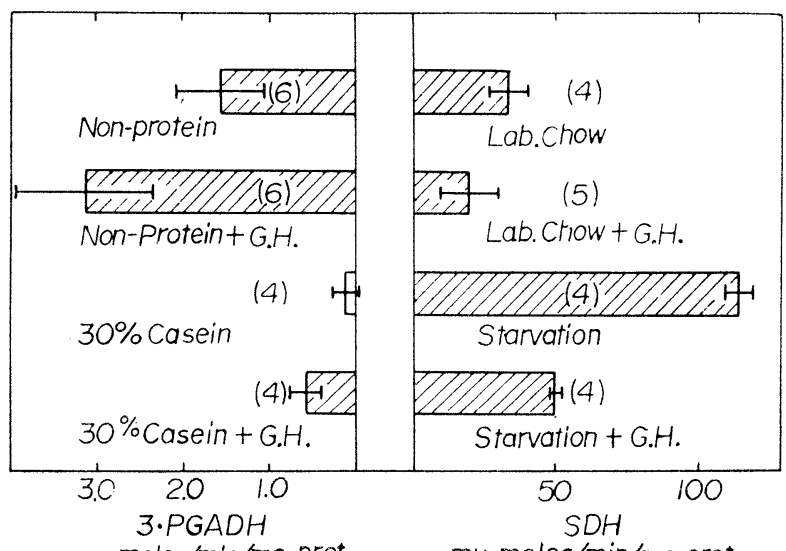

mu moles/min/mg prot. producer にあたる肝臓 脂肪組織, 或は小腸管などについては，むしろ anabolic function があり, 筋肉, 末梢血管, 心臓等心要物質の consumer にあたる器官では catabolic function があらわれるのである.

従つて, 例えば, hydrocortisone がアアルブミンの turnover を促 進するという知見は，人間及び動物 において報告されて居るが9(10)，プ ラスマ蛋白質は, 恒常性が維持され る機構の下にあるから, 未梢器官に おけるcatabolismが盛んで turnover が上昇するときは必ず，肝臓におけ るプラスマ蛋白の合成度がそれに見 合つて上昇する筈であり, 他面その message は拮抗するホルモンで消去 されるのが合目的である．Fig. 11は 前記, 肝臟環流で, アルブミンの合

Fig. 11. The effects of hormones on the synthesis of rat serum albumin in the isolated perfused rat liver. Approximately $100 \mathrm{ml}$ of blood were collected from 10 rats and centrifuged. The cell fraction precipitated was washed three times with a Ringer solution. Glucose $(1 \mathrm{mg} / \mathrm{ml})$ and heparin $(2000 \mathrm{u})$ were added to the Ringer media containing 2 per cent bovine albumin. The volume was finally adjusted to that of the original whole blood. After the perfusion, each $2 \mathrm{ml}$ of the perfusate was taken out at the interval as indicated inthe figure. After centrifugation, the sample was diluted with a Ringer solution to $4 \mathrm{ml}$ and $0.05 \mathrm{ml}$ aliquot of the diluted sample was mixed with $0.3 \mathrm{ml}$ of the anti-rat albumin serum from rabbit (lmg of which was enough to precipitate $2 \mathrm{mg}$ crystalline albumin). The reaction fluid was incubated for 1 hour at $37^{\circ}$ and then kept for additional 18 hours at $4^{\circ}$. The protein precipitated was dissolved in $0.5 \mathrm{~N} \mathrm{NaOH}$ and its concentration was determined by the method of Lowry et al The content of albuminwas calculated from the quantitatie precipitin reaction curve.

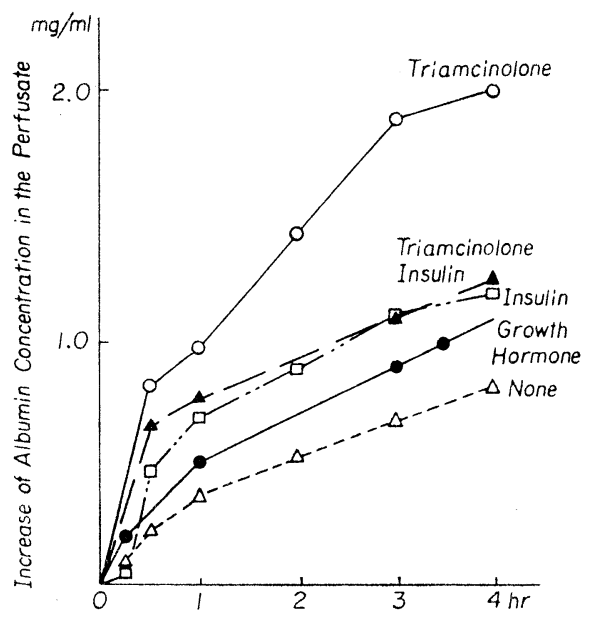

第 43 巻 第 5 号 
成速度が, triamcinolon $(10 \mathrm{mg} / 100 \mathrm{ml})$ 添加で促進されている事, 及びその促進は insulin $(40 \mathrm{u} . / 100 \mathrm{ml})$ で消却されている事実を初めて明にした私共の成績である，白鼠アルブミンを結晶化し，その家兔抗血清を 用いて定量沈降させて合成量を測定した，環流液は，牛アルブミン $2 \%$ 含有のリンゲルに，白鼠の赤血球そ の他の有形成分を元全血の割合に加えてある. 牛アルブミンは, 白鼠アルブミンの抗血清によつて沈降しな い. 尚, 最初約30分における急速はアルブミンの量的増加は, 貯蔵又は precursor からの release であつて, net synthesis でない，なぜかといえば，アミノ酸拮抗鼡で蛋白合成を阻害する，p-fluorophenylalanine を 還流液に入れると，最初の量的増大は阻害されないで第 2 首の合成度は，完全に阻害されるからである。 growth hormone (2I.U./100) はアルブミン合成の inducer にはなつていない.アルブミンの問題をててに とりあげたのは動物体内でアルブミンの turner over が，蛋白代謝の総括的な表現であるからである，尚， 白鼠の小腸管に対しては, insulin がアミノ酸の吸収を低下させ，アロキサン糖尿の時に上昇するてとを最 近私共の研究室で in vitro 系及び in vivo 系で明にした ${ }^{11)}$. 晹管でのアミノ酸吸収と肝臟でのアルブミン 合成が，ホルモンを介して同調するととが考劣られる。

\section{（4）今後の問題への考察}

以上(2)及び(3)の事実から序論で述べた様にホルモンの生理的役割として

(a) 律速䤏素の誘導形成汇関しては chemical messenger の間飞消去作用が存在する.

(b) 同種ホルモンが, 同一臟器内の細胞内で, 応答する酥素の機能上の質的差異 (anobolic enzyme か catabolic enzyme か) に照応して，一方を誘導合成しつつ，他方の活性が上昇しない様に作用する。

(c) この相反的作用機作 (dual mechanism) は，細胞内レベルだけでなく臓器間のレベルでも見られる. 此等の問題点を(1) molecular level への展開する方向と(2)他の多くのホルモンや更には自律中枢による代謝 律速を含めて全体としての恒常性維持機構の解明に向う方向とがあろう.

いづれにせよ，律速を受ける側の marker が蛋白分子こして純化分離され，穴の量的及び質的 (turnover) 分析が可能な時点から出発すべきであると思う.

今後の問題としては，代謝律速の場としてホルモンを考光るにしても，外部から摂取する栄養物質がなけ れば, 元来代謝自体もあり得ないわけで,この点在考觉ねばならない. 単細胞生物では, 外部の栄養物質, 或は代謝㦃物によつて酵素の誘導形 成或は repression がある。動物細 胞でも，組織培養によつててうした 現象が報告されている。更に動物を 特殊な栄養条件下で飼育した場合に も見られる。例えば Fig. 12 と見ら れたい, 白鼠を糖類, 脂質, 塩類, ビタミン混合及び蛋白質の代りに必 須アミノ酸と非必須ア之ノ酸のN源 としてクェン酸アンモンを加えた人 工食慨で飼育出来る．Fig. 12 で見 られる様に（非必須アミノ酸とし て serine を唯一の N源として添加 した場合約 2 日の Lag をおいて動 物は体重増加がある）この場合も， $3 \mathrm{PGDH}$ と $\mathrm{SDH}$ は全く相反的は消 長を示している. 3PGDH は, 食飰 中に serine が充分ある為に，ての

Fig. 12. Effect of dietary serine on rat liver 3-PGADH andSDH. For 3-PGADH experiment, rats were maintained for 5 days on a synthetic diet containing ammonium citrate ( 20 mmonium citrated iet) or serine $(40 \mathrm{mmoles} / 100 \mathrm{~g}$ diet, serine-diet) as non-essential amino nitrogen source. For $\mathrm{SDH}$, rats were fed for 5 days ammonium citrate-diet and then they were amintained for further 2 days on serine diet.

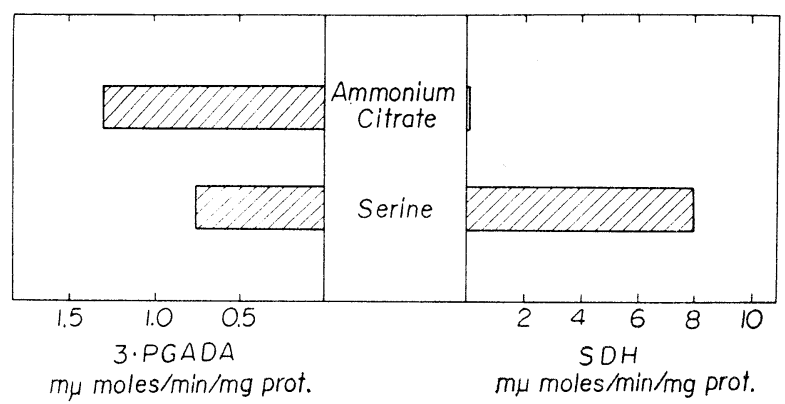


anabolic enzyme は repression を受け活性が低下し，一方，SDH の活性が上昇しないととには，動物は 非必要アミノ酸をつくる為のN源が不足する為，やむなくての catabolic enzyme の活性を誘導している. この様な条件下で起る両酵素の repression 及び adaptation に，果してホルモンがどの程度に介在してい ৩か, 問題である.

Fig. 12 の飼育条件では，糖類は充分に与えられ，肝臓が serine 在脱アミノ化して C骨格である pyruvate を，糖新生の為に利用する必要はない，事実 Fig. 13 で判る様に，上半の左右の column の関係をみて頂 きたい. プラスマ insulin の濃度と SDH 活性が相反的に変化し，アロキサン糖尿症では，insulin 量が低 くその場合 SDH 活性は高い. 下半がこれに対し, Fig. 12 と関係がある. 即ち, serine を唯一の非必須ア ミノ酸とした混合人工銅料で飼育した場合, プラスマ insulin 濃度は, クエン酸アンモンを serine の代り に加えて飼育した時よりもむしろ高い，にもかかわらず，SDH 活性も亦高い. insulin が predominantな 状況下では，SDH 活性は低く，3PGDH は高いのであるが，Fig. 12, Fig. 13 の場合は，両醉素の活性のあ

Fig. 13. Relationship between concentration of plasma insulin and liver SDH activity of rats.

Insulin was determined by the method of Hales and Randle using an immunoassay kit distributed by the Raidochemical Center. One group of rats fed a laboratory chow were intvravenously injected with recrystallized alloxan monohydrate $(7 \mathrm{mg} / 100 \mathrm{~g}$ body weight). 5 days after the treatment, the animals were sacrificed. Another group was maintasned for 7 days on a synthetic diet containing serine of ammonium citrate as non-essential amino nitrogen source.

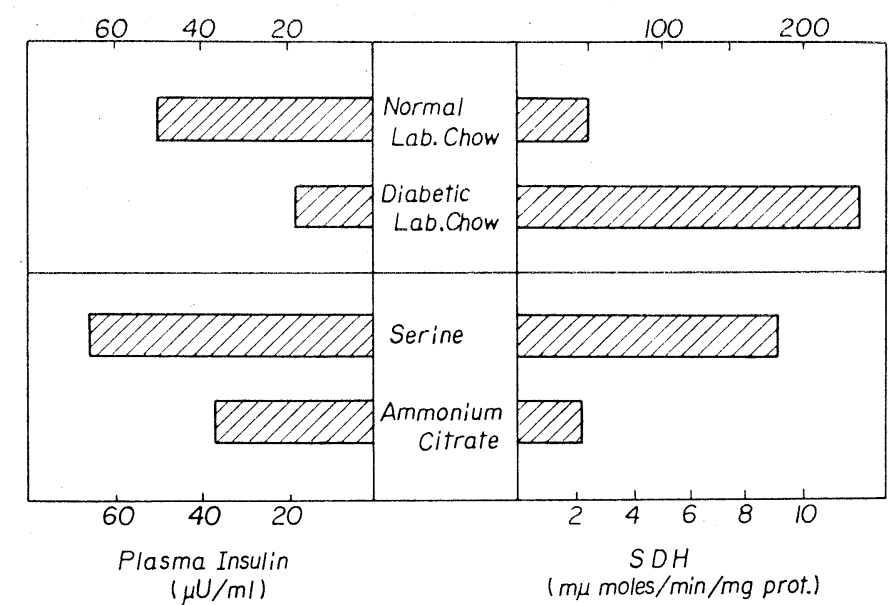

り方は，ホルモンの作動に逆つているかの様に見える。Knox ${ }^{12)}$, Schimke ${ }^{13)}$ らは肝臓で tryptophan pyrrolase が基質で誘導される現象をしらべ，てれは，in vivoでも，酥素蛋白の崩壊が tryptophan によつて防がれ ている為, 見掛け上の基質誘導が起つていることを明にしている. 然し必ずしも, それだけとは現在言いき れない事実もある。 serine dehydratase の serine による誘導はFig. 13 に示すでとく, serine は特微的 であるが，glycine でもかなりよく誘導されているのは Fig. 6 の metabolic map上で示す様に, serine hydeoxymethylase による glycine $\rightarrow$ serine への変化の結果と思われる。乙の hydroxymehylase 活性は $\mathrm{SDH}$ 活性の変動条件下で， SDH と同調的に変化する. glutamine 酸による誘導がみられる原因はよくわ からない.

䣼素基質或は，終末産物（この場合前者は serine による誘導，後者は serine による repression）が, 
Fig. 14. Effect of dietary amino acids on serine dehydratase induction. Male Wistar strain rats, weighing 150$170 \mathrm{~g}$, were maintained for 5 days on a synthetic diet containing ammonium citrate as non-essential amino nitrogen source. Then, they were maintained for further 5 days on diets containing various amino acids in place of ammonium citrate.

Serine Dehydratase Activity ( $\mathrm{mu}$ moles $/ \mathrm{min} / \mathrm{mg}$ prot.)

\begin{tabular}{|c|c|}
\hline \multicolumn{2}{|c|}{ 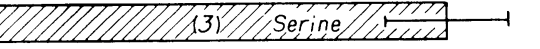 } \\
\hline 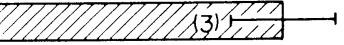 & Glycine \\
\hline 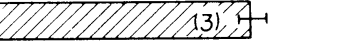 & Glutamic Acid \\
\hline 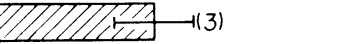 & Aspartic Acid \\
\hline DIDDDDA-4 & Alanine \\
\hline PDETEA & $\begin{array}{l}\text { Ammonium } \\
\text { Citrate }\end{array}$ \\
\hline 6 & 10 \\
\hline
\end{tabular}

更に単純な系でいえば，酵素の基質は，その酵素によ つて分解されると共に，一方では基質・酵素結合によ り基質は酵素蛋白の conformation 変化を起しアロス テリックな変化としてとらえられる場合もある.

高次元の生物一人間は言語と思想による信号系の 歴史的集積によつて，本能への制御と脱制御が，思考 過程で行われている。乙の次元へ達するてとは困難で あつても低次元のモデル実験では，いたづらに研究が 分極化するだけである.

ホルモンによる律速は，神経系によるミリ秒単位の 衝撃的律速と, 外部から摂取した栄養物質による代謝 の修飾又は情報とを，たくみに仲介して，代謝振幅を 少くするのに役立つているに相違ない。一我々は余 りに無知であるが.

最終に serine の合成系と分解系における律速の相 反的関係を一括して表にしてみた。（4月10日，1967 年)
高等動物の体内で, ホルモン制御に逆つてさえ, 栄養 要求に順応して代謝律速の酵素活性を維持する原因に つては，中枢的な制御があるのか，或は，ホルモン と基質の間に細胞内情報伝達系を介しての相互作用が あつて，例えば insulin が dominant であつても， serine が有効濃度に存在すると, hydrocortisone の 拮抗効果を増幅することがあつてもよい. 今後のひと つの課題にしておきたい，食物とホルモンの関係を， なぜこの様に重要視する必要があるかといえば，栄養 物質と体内代謝律速とは，相補的であつて，乙の相補 性の破綻が病態であるとと $\left.{ }^{14}\right) ，$ 次に栄羪物質は dual function をもつていて一方では代謝されて有効に利 用されると共に他方で, 情報伝達の役目をもつている という点である。例えば，血中グルコースは自律中枢 の glucoreceptor に作用して satiety center（副交感 系）左右するし，又膵臓の $\beta$ 細胞から insulin を放 出させる，弓狩らが，本シンポジウムで発表している 様に, 細胞内遊離高級脂酸は, 糖の分解系に関与する 律速酵素を不活化して, 糖の節約をし, acety CoAcarboxylase を不活化して脂酸合成を抑制している. 次元を越えずに，てうした面だけをとり上げれば，単 細胞生物にけられる feedback 機構と一致している。

Fig. 15. Reciprocal effects of hormones and diets on enzymes catalyzing anabolism and catabolism of serine. The data on the effect of glucagon was not presented in this paper, however, it could be shown that glucagon also had reciprocal effects on 3-PGADH and SDH.

\begin{tabular}{|c|c|c|c|}
\hline & & $\begin{array}{l}\text { 3.PGAOH } \\
\text { (anabolic) }\end{array}$ & $\begin{array}{c}\text { SDH } \\
\text { (catabolic) }\end{array}$ \\
\hline \multirow{4}{*}{$\begin{array}{l}\text { Hormonal } \\
\text { Control }\end{array}$} & Insulin & $\uparrow$ & $\downarrow$ \\
\hline & Glucocorticoid & $\downarrow$ & 1 \\
\hline & $\begin{array}{l}\text { Growth } \\
\text { Hormone }\end{array}$ & 1 & 1 \\
\hline & Glucagon & $\downarrow$ & $\uparrow$ \\
\hline \multirow{3}{*}{$\begin{array}{l}\text { Dietary } \\
\text { Control }\end{array}$} & High protein & 1 & 1 \\
\hline & Non-protein & $\uparrow$ & 1 \\
\hline & Starvation & $\downarrow$ & $\uparrow$ \\
\hline \multicolumn{2}{|c|}{ Feedback Repression } & + & \\
\hline Substrate & Induction & & + \\
\hline
\end{tabular}

追記：歴史のある内分泌学会において，私共の未熟な研究を特別に発表させて頂けた機会を与えられまし た会長山田弘三教授に感謝致します。此等の研究は, 阪大蛋白研代謝部門において, 石川, 中川博士，弓狩 助教授, 大学院学生, 森村, 木村, 黒田, 陶, 三浦学士, 及び阪大医学部栄鏊学教室の後任である田中教授, 
及び林博士らの協力によつたものであるととを, 記述して門下の諸氏に深く謝意を表します，尚，蛋白研共 同研究員として来所された佐久間（東大・医・中尾内科）, 内藤 (岐阜薬大・生化学), 小畠 (国立栄養研) の 諸氏の協力に御礼申し上げます。

\section{文献}

1) ISHIKAWA, E., NINAGAWA, T., SUDA, M. : J. Biochm. (Tokyo), $57: 506$ (1965).

GOLDSTEIN, L., STELLA, J.E., and KNOX, W.E. : J Biol. Chem., 237 : 1723 (1962).

MILLER, L.L. : Recent Prog. Hormone Res., 17, 539 (1961)

4) 田中武彥, 黒田剛生, 森村弘子,

原納 優, 陶文 暁, 須田正已：医化学ムンポジウム, 第 6 集, (1967年), 印刷中.

5) SOLS, A., SALAS, M., and VINUELA, "Advances in Enzyme Regulation", Ed. by G. Weber, Pergamon Press Inc., New York, Vol. 2, p. 177 (1963).

6) WALKER, D.G. : Biochem. J., 88 : 179 (1963).

7）田中武彥, 但野道臣, 森 亮介, 須田正已 : 第16回酵素化学シンポジゥム，予稿集，111頁，1964年.

8) SALLAGH, H.J. : J. Biol. Chem., $223: 1101$ (1956). 9) Rothschild, M.A. : J. Glin. Invest. 36: 422 (1957); ibid $37: 1229$ (1958), ibid $40: 545$ (1961). 10) GROSSMAN, J. : Metabolism, 9, 528 (1960). 11）弓狩康三：第17回日本医学会総会シンポジゥム(名古屋)発表。 12$)$ KNOX, W. E. : "Advancesin Enzyme Regulation”, Ed. by A. Weber, Pergamon Press Inc., New York, Vol. 2, p. 311 (1964). 13) SCHMIKE, RT, SWEENEY, E.W., and BERLIN, G.M. : J. Biol. Chem., $240 ： 4609$ (1965). 14）須田正已：「高等動物，植物，細菌に打ける代謝調節の合目的性について」 蛋白鏡・核酸・酵素(共立出版社) Vol. 10, No. 73 頁，（1965年） 